\title{
The clinical, laboratory, and microbiological profile of patients with sepsis at the Internal Medicine Inpatient Unit of Dr. Cipto Mangunkusumo National General Hospital, Jakarta
}

\author{
Djoko Widodo
}

\begin{abstract}
Abstrak
Manifestasi klinis sepsis berupa systemic inflammatory response syndrome/SIRS, terdapatnya infeksi dan disfungsi organ merupakan kriteria yang digunakan dalam diagnosis sepsis saat ini. Pada 2 tahun terakhir berkembang pemikiran untuk menambahkan beberapa parameter disamping kriteria tersebut, dengan diajukannya terminologi PIRO (P: predisposition, I: infection, R: response dan O: organ failure). Manifestasi klinis sepsis di tiap rumah sakit maupun unit perawatan dapat berbeda bergantung dari beratnya sepsis, fokus infeksi, komorbiditas dan disfungsi atau kegagalan organ. Pada penelitian ini akan dievaluasi data demografi, komorbiditas, sumber infeksi, manifestasi SIRS, disfungsi organ dan profil mikrobiologik sepsis di rawat di Unit Penyakit Dalam RSUPN Dr. Cipto Mangunkusumo, Jakarta. Dilakukan penelitian deskriptif korelatif dengan disain potong lintang, pada 42 subyek dengan sepsis, sepsis berat dan renjatan septik. Penelitian dilakukan di Unit Rawat RSPUN Dr. Cipto Mangunkusumo, Jakarta pada tahun 2002. Dilakukan pencatatan data klinis, laboratorium (hematologi, biokimia, analisis gas darah) dan kultur aerob (darah dan spesimen lain). Kriteria sepsis yang digunakan berdasarkan American College of Chest Physician dan Society of Critical Care Medicine tahun 1992. Hasil penelitian menunjukkan terdapatnya distrubusi sepsis yang proporsional menurut usia dan jenis kelamin, komorbiditas didapatkan pada $88 \%$ subyek, berupa diabetes melitus dan penyakit kronik lainnya. Sumber infeksi terbanyak berasal dari paru, kulit-jaringan lunak, abdomen dan traktus urinarius; dengan gambaran kuman Gram negatif lebih banyak dari Gram positif. Manifestasi SIRS didapatkan pada lebih dari $70 \%$ subyek dengan manifestasi terbanyak berupa takikardia dan takipnu. Manifestasi disfungsi organ terbanyak berupa penurunan kesadaran, asidosis metabolik, disfungsi renal dan penurunan tekanan arteri rata-rata, dan didapatkan korelasi parameter tersebut dengan derajat sepsis. (Med J Indones 2004; 13: 90-5)
\end{abstract}

\begin{abstract}
At the moment, the diagnosis of sepsis is established based on the criteria of the presence of a clinical manifestation of systemic inflammatory response syndrome/SIRS, infection, and organ dysfunction. In the last two years, the idea to add several additional parameters to these criteria has developed, with the proposition to use the acronym PIRO (P: predisposition, I: infection, R: response and $O$ : organ failure). Clinical manifestations of sepsis at each hospital or treatment unit may differ according to the severity of sepsis, the focus of infection, comorbidity, and organ dysfunction or failure. This study evaluated the demographic, comorbidity, source of infection, SIRS manifestation, organ dysfunction, and microbiological profile of sepsis at the Internal Medicine Inpatient Ward of Dr. Cipto Mangunkusumo National General Hospital, Jakarta. A correlative, cross-sectional, descriptive study was performed on 42 subjects with sepsis, severe sepsis, and septic shock. The study was performed at the Inpatient Ward of Dr. Cipto Mangunkusumo National General Hospital, Jakarta, in the year 2002. Clinical and laboratory (hematological, biochemical, and blood gas analysis) data, as well as results of aerobic cultures of the blood and other specimens were recorded. The criteria of sepsis used were based on that of the American College of Chest Physician and the Society of Critical Care Medicine in 1992. The results of the study demonstrated a proportional distribution of sepsis based on age and sex, with comorbidity in $88 \%$ of subjects, consisting of diabetes mellitus and other chronic diseases. The most common sources of infection were the lungs, skin-soft tissues, abdomen, and urinary tract, with Gram-negative bacteria more commonly found than Gram-positive bacteria. SIRS manifestation was found among over $70 \%$ of subjects, with the most common manifestations being tachycardia and tachypnea. The most common manifestations of organ dysfunction were reduced consciousness, metabolic acidosis, renal dysfunction, and a lower mean arterial pressure. There was a correlation between these parameters and the degree of sepsis. (Med J Indones 2004; 13: 90-5)
\end{abstract}

Keywords: sepsis, clinical manifestation, microbiology

Department of Internal Medicine, Division of Tropical Medicine and Infectious Diseases, Faculty of Medicine University of Indonesia/Dr. Cipto Mangunkusumo General Hospital, Jakarta, Indonesia 
circulation, activating the inflammatory process. ${ }^{1-3}$ In the United States in the last 20 years, the incidence rate of sepsis has risen to an estimated 400,000500,000 every year. ${ }^{4}$ Factors that are associated with the increased rate of sepsis is the ability of doctors to diagnose sepsis at an earlier stage, increased immunocompromised patients, increased use of invasive procedures, increased microorganism resistance, and an increased number of elderly patients susceptible to infection and sepsis. ${ }^{1}$ Data from the medical record of Dr. Cipto Mangunkusumo National General Hospital in 1999 found 92 cases of sepsis, 70 of which (78.3\%) died, while in the year 2000 there were 160 cases, 135 of which died $(84.4 \%){ }^{5}$

In1992, the American College of Chest Physician and Society of Critical Care Medicine consensus established definitions for sepsis, systemic inflammatory response syndrome (SIRS), severe sepsis, and septic shock. These terms are still used in clinical application up to now, considering the need for a practical guideline to recognize signs and symptoms of sepsis before falling into severe sepsis and organ failure. ${ }^{3}$ In the $31^{\text {st }}$ International Educational and Scientific Symposium of the Society of Critical Care Medicine in 2002, several objections were raised about the criteria for sepsis. Panelists realized that the current criteria for sepsis are too sensitive and not specific, particularly for use in epidemiological surveys and clinical trials. Aside from the criteria of SIRS with a focus of infection, several additional criteria were proposed, such as reduced consciousness, olyguria, skin manifestations, hypoglycemia, and thrombocytopenia. The acronym PIRO (P: predisposition, I: infection, R: response and $\mathrm{O}$ : organ failure) was also proposed. ${ }^{6}$

Data on the manifestations of sepsis from each hospital (public or private), care unit (medical, burns, surgical, or intensive care units) may differ due to the severity of sepsis, the focus of infection, comorbidity, and organ dysfunction or failure. Early diagnosis and causal treatment including the administration of antimicrobial agents highly influence the success of treatment. ${ }^{7}$ In this study, we evaluated data on the demographics, comorbidity, source of infection, SIRS manifestation, organ dysfunction, and microbiological profile of patients with sepsis at the Internal Medicine Inpatient Unit of Dr. Cipto Mangunkusumo National General Hospital, Jakarta. This data could be used to recognize early signs of sepsis and provide guidelines for empirical administration of antimicrobial agents.

\section{METHOD}

The study was performed in the Internal Medicine Inpatient Unit of Dr. Cipto Mangunkusumo National General Hospital, Jakarta, from February to July 2002 , along with the study on coagulation in sepsis. The study was designed to be cross-sectional. As many as 42 patients who fulfilled the criteria of sepsis, severe sepsis, and septic shock were willing to participate in the study (consent was obtained from the patient or closest relative). Clinical details and blood specimen for hematological and biochemical assessment as well as microbiological culture were taken from the source of infection. Patients with decompensated liver cirrhosis, nephrotic syndrome, blood malignancy, severe trauma, and pregnancy were not included in the study.

The samples taken for aerobic blood culture were performed under aseptic conditions using a sterile syringe. ${ }^{8}$ As much as $5 \mathrm{ml}$ of blood sample was inserted into a Bac-T-alert medium (Roche Diagnostic), and underwent aerobic culture. Other samples from the focus of infection (pus and urine) were sent using transport medium to undergo aerobic culture. Microbiological assessments were performed at the Clinical Microbiology Laboratory of the Faculty of Medicine, University of Indonesia.

Study variables included sex, age, comorbidity, focus of infection, clinical diagnosis, SIRS manifestation, organ dysfunction, and the microbiological profile from blood culture or other specimens from the focus of infection. The criteria for sepsis used was based on that of the American College of Chest Physician and Society of Critical Care Medicine, 1992. ${ }^{3}$ Infection was established clinically and microbiological. A probable infection pertains to conditions with clinical manifestations of infection (pneumonia, urinary tract infection, etc) with a negative culture result. A definite infection pertains to conditions with positive microbiological culture from the blood or other specimens. ${ }^{9}$

Data sorting and analysis was performed using a statistical computer program. Univariant analysis of numeric variables was portrayed in the form of mean, median, standard deviation, minimum and maximum, categorical variable and proportion. 


\section{RESULTS}

There were 42 subjects who participated in the study, aged 19 to 78 years, consisting of 22 females and 20 males. Eleven subjects fulfilled the criteria for sepsis $(26.2 \%), 20$ subjects for severe sepsis $(47.6 \%)$, and 11 subjects for septic shock $(26.2 \%)$. Chi-square analysis found a proportional distribution among these groups (Table 1). Chi-square test and Spearman correlation did not find a significant correlation between age and the degree of sepsis ( $>00.05)$.

The most common sources of infection in this study were the lungs, skin and soft tissue, abdomen, and urinary tract. (Table 1). Lung infection comprised of pneumonia, skin and soft tissue infection erysipelas, gangrene and decubitus ulcer; intra-abdominal infection in the form of cholecystitis, cholangitis and peritonitis, urinary tract infection in the form of pyelonephritis.

Table 1. Subjects characteristics $(n=42)$

\begin{tabular}{llrr}
\hline & & $\mathrm{n}$ & $\%$ \\
\hline \multirow{2}{*}{ Age $(\text { years })^{*}$} & $\leq 40$ & 19 & 45.2 \\
& $41-59$ & 11 & 28.6 \\
& $\geq 60$ & 11 & 28.6 \\
Sex* & male & 22 & 52.4 \\
& female & 20 & 47.6 \\
Sepsis severity* & sepsis & 11 & 26.2 \\
& severe sepsis & 20 & 47.6 \\
& septic shock & 11 & 26.2 \\
& lung & 31 & 73.8 \\
& skin and soft tissue & 10 & 23.8 \\
& abdomen & 7 & 16.6 \\
& urinary tract & 7 & 16.6 \\
& heart & 3 & 7.2 \\
& systemic & 2 & 4.7 \\
& central venous catether & 1 & 2.4 \\
& ENT & 1 & 2.4 \\
\hline
\end{tabular}

* Chi-square test $\mathrm{p}>0.05$

Comorbidities that act as a risk factor and aggravating factor of sepsis were found among $88.1 \%$ of the subjects, comprising of diabetes mellitus, cardiovascular disease, cerebrovascular disease, chronic liver and renal disease, malignancy, or HIV infection (Table 2).
Table 2. Comorbidity and underlying diseases in septic patients $(n=42)$

\begin{tabular}{lrc}
\hline & $\mathrm{n}$ & $\%$ \\
\hline Diabetes mellitus & 14 & 33.3 \\
Cardiovascular diseases & 8 & 19 \\
Cerebrovascular diseases & 5 & 11.9 \\
Chronic kidney disease & 5 & 11.9 \\
Chronic liver disease & 3 & 7.1 \\
Malignancy & 1 & 2.3 \\
HIV & 1 & 2.3 \\
Absent & 5 & 11.9 \\
\hline
\end{tabular}

The SIRS manifestations found among sepsis patients comprised of a body temperature of $>38^{\circ} \mathrm{C}$ (in $73.8 \%$ of subjects) and $<36^{\circ} \mathrm{C}$ (in $4.8 \%$ of subjects); a heart rate of $>90 \mathrm{x} /$ minute in $100 \%$ of subjects, a respiratory rate of $>20 \mathrm{x} /$ minute in $95.2 \%$ of subjects, a pC02 of $<32 \mathrm{mmHg}$ in $78.6 \%$ of subjects and leukocytosis of $>1.2 \times 10^{3} / \mathrm{mm}^{3}$ in $78.6 \%$ of subjects. The manifestations of organ dysfunction were a GCS of $<15$ in $71.4 \%$ of subjects, a $\mathrm{HCO} 3$ of $<22 \mathrm{mEq} / \mathrm{l}$ in $69 \%$ of subjects, a hematocryte of $<30 \%$ in $69 \%$ of subjects, a platelet count of $<100,000$ in $35.7 \%$ of subjects, a serum creatinine of $>2 \mathrm{mg} / \mathrm{dl}$ in $45.2 \%$ of subjects, a serum albumin of $<2.5 \mathrm{mg} / \mathrm{dl}$ in $33.3 \%$ of subjects, a $\mathrm{PaO} 2$ of $<70 \mathrm{mmHg}$ in $33.3 \%$ and an MAP of $<70 \mathrm{mmHg}$ in $19 \%$ of subjects. (Table 3)

Table 3. SIRS manifestation and organ dysfunction in septic patients

\begin{tabular}{lcc}
\hline & $\mathrm{n}$ & $\%$ \\
\hline SIRS & & \\
Heart rate $>90 \mathrm{x} /{ }^{\prime}$ & 42 & 100 \\
Respiration rate $>20 \mathrm{x} /{ }^{\prime}$ & 40 & 95.2 \\
$\mathrm{PCO}_{2}<32 \mathrm{mmHg}$ & 33 & 78.6 \\
WBC $>1.210^{3} / \mathrm{mm}^{3}$ & 33 & 78.6 \\
Body temp $>38^{\circ} \mathrm{C}$ & 31 & 73.8 \\
Body temp $<36^{\circ} \mathrm{C}$ & 2 & 4.8 \\
Organ dysfunction & & \\
GCS $<15$ & 30 & 71.4 \\
HCO3 $<22 \mathrm{meq} / \mathrm{l}$ & 22 & 69 \\
Hematocrit $<30 \%$ & 29 & 69 \\
Serum creatinin $>2 \mathrm{mg} / \mathrm{dl}$ & 19 & 45.2 \\
Platelet $<100.000$ & 13 & 35.7 \\
Albumin $<2,5 \mathrm{mg} / \mathrm{dl}$ & 14 & 33.3 \\
PaO2 $<70 \mathrm{mmHg}$ & 14 & 33.3 \\
MAP $<70 \mathrm{mmHg}$ & 8 & 19 \\
\hline
\end{tabular}

The distribution of SIRS manifestations and organ dysfunction in the sepsis, severe sepsis and septic shock group resulted in a mean and standard deviation as portrayed in Table 4 . 
Statistical analysis using the Kruskal Wallis test to differentiate the three groups found a significant difference for the following parameters: serum creatinine, mean arterial pressure, consciousness (GCS), and bicarbonate concentration $(\mathrm{p}<0.05)$.

Blood bacteriological isolate was positive in $33.3 \%$ subjectsm comprising of Gram-positive bacteria in 7.1\%, Gram-negative bacteria in $19.1 \%$, and a combination of Gram positive and negative bacteria in $2.4 \%$. Specimen culture from the site of infection (from sputum, pus and urine) was performed in 12 subjects, resulting to be Gram-positive in 2 subjects, Gram-negative in 8 subjects, and a combination of Gram positive and negative in 1 subject. A definite diagnosis was obtained from 20 out of 42 subjects $(47.6 \%)$. The bacteriological profile from blood, sputum, pus and urine samples could be found in Table 5.

Table 4. Distribution of SIRS manifestation and organ dysfunction according to sepsis severity (mean+SD) in 42 sepsis patients

\begin{tabular}{|c|c|c|c|c|}
\hline & sepsis & severe sepsis & septic shock & $\mathrm{p}^{* *}$ \\
\hline \multicolumn{5}{|l|}{ SIRS } \\
\hline Heart rate & $111.7 \pm 9.6$ & $116.7 \pm 10.1$ & $113.3 \pm 14.7$ & 0.316 \\
\hline Body temperature & $38.8 \pm 1.1$ & $38.6 \pm 1.3$ & $38.8 \pm 1.6$ & 0.875 \\
\hline Respiration rate & $35.1 \pm 6.1$ & $32.2 \pm 6.8$ & $31.8 \pm 12.4$ & 0.653 \\
\hline $\operatorname{WBC}\left(10^{3}\right)$ & $19.77 \pm 9.05$ & $20.47 \pm 8.22$ & $18.07 \pm 12.99$ & 0.944 \\
\hline $\mathrm{PCO}_{2}$ & $24.99 \pm 8.64$ & $28.77 \pm 8.36$ & $23.61 \pm 11.51$ & 0.132 \\
\hline \multicolumn{5}{|l|}{ Organ dysfunction } \\
\hline $\mathrm{PaO} 2$ & $80.1 \pm 21.3$ & $90.15 \pm 39.4$ & $102.9 \pm 48.7$ & 0.800 \\
\hline Serum creatinin & $1.16 \pm 0.48$ & $2.28 \pm 1.60$ & $3.45 \pm 2.12$ & $0.001 *$ \\
\hline Albumin & $2.81 \pm 0.67$ & $2.84 \pm 0.73$ & $2.96 \pm 0.78$ & 0.871 \\
\hline Hematocrit & $24.0 \pm 7.14$ & $26.7 \pm 4.4$ & $28.1 \pm 8.3$ & 0.613 \\
\hline Platelet & $242 \pm 182$ & $212 \pm 153$ & $123 \pm 147$ & 0.060 \\
\hline MAP & $78.2 \pm 11.6$ & $80.17 \pm 10.36$ & $71.0 \pm 17.8$ & $0.044 *$ \\
\hline GCS & $15 \pm 0$ & $10.8 \pm 4.4$ & $10.7 \pm 3.6$ & $0.000 *$ \\
\hline $\mathrm{HCO} 3$ & $18.5 \pm 6.1$ & $18.9 \pm 5.9$ & $13.4 \pm 5.0$ & $0.039 *$ \\
\hline
\end{tabular}

* Significant $\mathrm{p}<0.05 \quad * *$ Kruskal Wallis test

Table 5. Microbiological profile in sepsis patients $(n=42)$

\begin{tabular}{|c|c|c|c|c|}
\hline Microogranism & blood & pus & sputum & urine \\
\hline \multicolumn{5}{|l|}{ Gram positive } \\
\hline Staphylococcus epidermidis & 3 & 1 & - & - \\
\hline Staphylococcus saprophiticus & - & - & 1 & - \\
\hline Streptococcus viridans & 1 & - & - & - \\
\hline Streptococcus anhemolyticus & - & 1 & - & - \\
\hline \multicolumn{5}{|l|}{ Gram negative } \\
\hline Pseudomonas sp. & 1 & 1 & - & - \\
\hline Pseudomonas paucimirabilis & - & - & 1 & - \\
\hline Proteus mirabilis & 1 & 2 & 1 & - \\
\hline Klebsiella pneumonia & 1 & - & - & - \\
\hline Klebsiella oxytoca & 1 & - & - & - \\
\hline Klebsiella sp & - & 1 & - & - \\
\hline Enterobacter aerogenes & 2 & 1 & 1 & - \\
\hline E. coli & 1 & 1 & - & - \\
\hline Alcaligenes fecalis & 1 & - & - & - \\
\hline Acinetobacter & 1 & - & - & 1 \\
\hline Vibrio & - & - & 1 & - \\
\hline Fungi & 1 & - & 1 & - \\
\hline
\end{tabular}


In Table 6, we found that subjects with a Gramnegative infection and a combination of Gram positive and negative infections tend to suffer from severe sepsis and septic shock, but the tendency was not found to be statistically significant (Chi square $\mathrm{p}>0.05)$.

Table 6. Correlation between microbiological type and and sepsis severity

\begin{tabular}{lrrr}
\hline & sepsis & severe sepsis & septic shock \\
\hline Gram positive & 2 & 1 & - \\
Gram negative & 3 & 4 & 2 \\
Mixed infection & - & - & 1 \\
\hline
\end{tabular}

Chi square $\mathrm{p}=0.307$

Spearman correlation $\mathrm{r}_{\mathrm{s}}=0.484 \quad \mathrm{p}=0.094$

\section{DISCUSSION}

The clinical profile of patients with sepsis at the Internal Medicine Inpatient Unit of Dr. Cipto Mangunkusumo National General Hospital demonstrated a proportional distribution for all age groups and each sex. Sepsis could occur in all age groups and sex, even though various previous studies found that the elderly were more susceptible and suffered from more severe manifestations of sepsis. ${ }^{1}$ In this study, no correlation was found between age and the severity of sepsis, which is due to various other factors that also play a role in the development of sepsis in the young, such as chronic disease and immunocompromised conditions.

In this study, we found an equal distribution of sepsis, severe sepsis, and septic shock, which differs from the results of various epidemiological surveys that found sepsis to be the most frequent case, followed by severe sepsis, and the least being septic shock. This is because early sepsis is often unrecognized / undiagnosed or the patient may not have had the chance to come to the hospital, and is thus diagnosed as its primary illness.

Comorbidity seems to play a significant role in the development of sepsis, as seen from its presence among $88 \%$ of subjects. The most common comorbidity is diabetes mellitus, cardiovascular and cerebrovascular disease, chronic liver and renal disease, malignancy, and HIV. As from the results of previous studies, comorbidity is a risk factor for the development of sepsis. ${ }^{1}$

Clinical manifestations of sepsis in the form of SIRS manifestations were found among over $70 \%$ of subjects, the most being tachycardia, tachypnea / reduced $\mathrm{PCO} 2$, and leukocytosis. Manifestations of organ dysfunction may also support the diagnosis of sepsis, which were reduced consciousness, reduced bicarbonate concentration, reduced hematocryte levels, and increased serum creatinine levels. Several manifestations of organ dysfunction, such as reduced GCS, increased serum creatinine, reduced bicarbonate, and MAP, could determine the degree of sepsis.

The most common sources of infection in this study were the lungs, skin and soft tissue, abdomen, and urinary tract. As in previously publicized reports, the lungs, abdomen, and urinary tracts are the most common sources of sepsis. ${ }^{10}$

From the microbiological profile of the blood isolate obtained in this study, Gram-negative bacteria was still more frequently found compared to Grampositive bacteria. There was a tendency towards an increase in Gram-positive infections, particularly among cases of drug-abuse endocarditis. The Gramnegative bacteria found were mostly due to nosocomial infections, such as Pseudomonas, Klebsiella, Enterobacter and E. coli infections. Considering that the blood culture turned out positive for only one third of the subjects, and several days were needed to obtain the results, antimicrobial agents were generally administered empirically. Rapid and accurate empirical administration of antimicrobial agents is one of the factors that influenced the success of treatment for sepsis. ${ }^{11,12}$

The use of the PIRO (Predisposition, Infection, Response, Organ Failure) criteria aside from SIRS manifestation, as portrayed in this study, is considered to be relevant and to support the acuracy of the diagnosis of sepsis.

\section{CONCLUSION}

The clinical manifestations of patients with sepsis at the Internal Medicine Inpatient Unit of Dr. Cipto Mangunkusumo National General Hospital demonstrate a proportional distribution of sepsis according to age and sex. Comorbidity was found among $88 \%$ subjects, in the form of diabetes mellitus and other chronic 
diseases. The most common sources of infection in this study were the lungs, skin and soft tissue, abdomen, and urinary tract, with Gram-negative bacteria more commonly encountered than Grampositive bacteria. SIRS manifestations were found among over $70 \%$ of subjects, with the most common manifestations being tachycardia and tachypnea. The most common manifestations of organ dysfunction were reduced consciousness, metabolic acidosis, renal dysfunction, and reduced mean arterial pressure, with a correlation between these parameters and the degree of sepsis.

\section{REFERENCES}

1. Balk RA. Severe sepsis and septic shock, definition, epidemiology and clinical manifestation. Crit Care Clin 2000;16(2):179-92.

2. Bone RC. Let's agree on terminology: definitions of sepsis. Crit Care Med 199 v 1;19(7):973-6.

3. Members of the American College of Chest Physician/Society of Critical Care Medicine Consensus Conference Committee. American College of Chest Physician/Society of Critical Care Medicine Consensus Conference: Definition for sepsis and organ failure and guidelines for the use of innovative therapies in sepsis. Crit Care Med 1992;20:864-74.
4. Wenzel RP. Epidemiology of sepsis. N Eng J Med 2002;347:966-7

5. Data from Medical Record Dr. Cipto Mangunkusumo General Hospital, Jakarta, Indonesia, year 1999-2000 (in Press)

6. Martin GS. Sepsis: an evolution of concept and definitions.[cited 2002 April 11]. Available from: http://www.medscape.com/viewarticle/427188.

7. Lodise TP, Mc Kinnon PS, Swiderski L, Rybak MJ. Outcomes analysis of delayed antibiotic treatment of hospital acquired Staphylococcus bacteremia. Clin Infec Dis 2003;36(11):1418-23.

8. Suhendro. Bacterial culture examination. In: Sumaryono, Alwi I, Sudoyo AW, Simadibrata M, Setiati S, Gani RA, Mansjoer A, editors. Medical procedure in Internal Medicine (Indonesia), Jakarta: Internal Medicine Department (Publication and Information Center), Faculty of Medicine University of Indonesia. 1999. p.237-41.

9. Azoulay E, Chevret, Didier J, Neuville S, Barboteu M, Bornstain C, et al. Infection as a trigger of diabetic ketoacidosis in intensive care unit patients. Clin Infec Dis 2001;32:90-5.

10. Wheler AP, Bernard GR. Treating patient with severe sepsis. New Eng J Med 1999;340:207-14.

11. Hanon FX, Monnet DL, Sorensen TL, Molbak K, Pedersen G, Schonheyder H. Survival of patients with bacteremia in relation to initial empirical antimicrobial treatment. Scan J Infec Dis 2002;34(7):520-8.

12. Fish DN. Optimal antimicrobial therapy for sepsis. Am J Health Syst Pharm 2002;59 Suppl1:S13-9. 